É Doutora em Sociologia pela Universidade de Brasília (UnB) e pósdoutora em Ciências Sociais pela Universidade do Vale do Rio dos Sinos (Unisinos). É professora de sociologia da Escola de Formação de Professores e Humanidades da PUC Goiás e do Programa de PósGraduação em História/PUC Goiás. É assessora de pesquisa do Instituto Dom Fernando (PUC Goiás), editora da Revista Mosaico e editora adjunta da Revista Arquivos do CMD.

\section{Subjetividade e Memória Social: uma abordagem transdisciplinar}

Thais Alves Marinho*

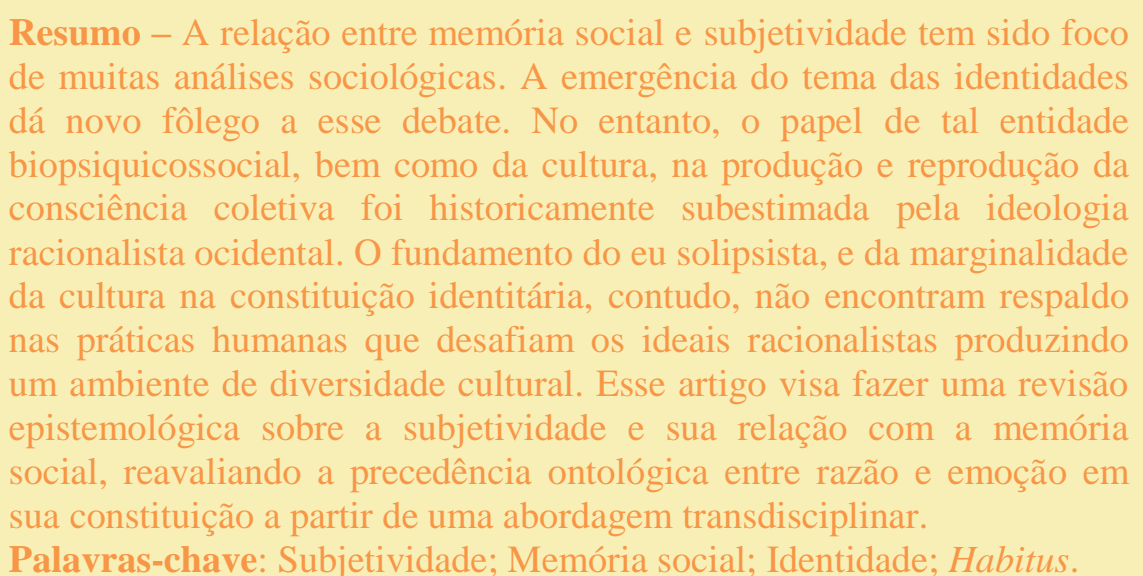

Abstract - The relationship between social memory and subjectivity has been the focus of many sociological analysis. The emergency of the identity's theme gives this debate new impetus. However, the role played by such biosocialpsychic entity, as well the one played by culture, on the production and reproduction of collective consciousness has been historically underestimated by western rationalist ideology. The foundation of solipsistic self and of the marginalization of culture in the dentity constitution, nevertheless, is not supported by human practices which challenge the rationalist ideals producing an environment of cultural diversity. This article aims to do an epistemological review on subjectivity and its relationship to social memory, reassessing the ontological precedence between reason and emotion in its constitution rom a transdisciplinar approach.

Key-words: Subjectivity; Social memory; Identity; Habitus 


\section{Introdução}

A pluralidade e a complexidade das organizações humanas atuais dão novo fôlego ao tradicional problema sociológico em compreender as relações entre indivíduo e sociedade, entre agente e estrutura, entre o sujeito e a consciência coletiva. Desde o surgimento e consolidação da sociologia, esse debate tem sido prioritário entre os cientistas sociais, que desenvolveram métodos próprios para lidar com tal dilema, mas sustentaram-se em pressupostos filosóficos racionalistas, associados com as expectativas da agenda universalista da modernidade.

Logo, grande parte do discurso sociológico pressupõe que a reflexividade individual levaria os agentes a abandonar suas pertenças comunais (solidariedade mecânica), marcadas por elevados níveis de consciência coletiva, em favor de uma diferenciação crescente que configuram as sociedades humanas modernas e individualizadas (solidariedade orgânica), cujas entidades socializadoras são constituídas pelo estado, por meio da escola e do mercado de trabalho.

A prerrogativa é de que tal indivíduo moderno, centrado em si mesmo, formalizaria as estruturas sociais em prol de um cálculo utilitarista, que fundamenta suas escolhas e opções de vida, de forma otimizante e universal. No entanto, a irredutível pluralidade demonstra que o que há de evidente em todas as assertivas sobre o indivíduo moderno e sua subjetividade é o fato de que a consciência cognitiva apresenta limites para a conformação da realidade. Já percebidas pelos primeiros estudiosos, tais lacunas, eram explicadas em tons de desvios, como as emoções, conforme aparece em Weber (2003), Durkheim (2003), Marx (1988), James (1952), Wundt (1904), Mead (1993), Bartlett (1961) e Dewey (1959); ou eram camufladas por expectativas metafísicas, nas quais se inserem a imaginação, como em Bachelard (1978), a linguagem, como em Ricouer (2000), o inconsciente, como em Freud (1996), Lacan (1999), Foucault (1979) e Benjamin (1986), e que em outras versões, como a positivista, se associam a uma metafísica da biologia, contida nos genes.

As emoções nessas perspectivas racionalistas têm figurado como uma instância que não é voluntariamente exposta pela consciência, a menos que ela falhe, por defeito ou desvio, seja falta de inteligência ou algum distúrbio ou deficiência, que levam à loucura ou ao comprometimento da cognição, ou por privação de informações seja de ordem moral e/ou intelectual. A baixa patente adquirida pela emoção devido à ascensão do desencantamento racionalista faz erigir todo um sistema de autocontrole consciente das emoções, visualizado por meio de instituições sociais, como demonstram Elias (1994), Foucault (2009), Benjamin (1985), Adorno e Horkheimer (1995), o que estabelece os pilares das civilizações humanas ocidentais e de suas estruturas sociais. Nessas perspectivas, a emoção vista como vocação artística, 
associada ao senso estético do juízo do gosto ou do sentimento do prazer, melhora de condição, passando a critério de originalidade e autenticidade relacionado ao potencial mimético humano, como um último fôlego da gnosiologia substancialista de Aristóteles (1996), presente também em Rousseau.

As indicações sobre essa instância negligenciada do ego transcendental, enquanto princípio de constituição de todo sentido do mundo, mesmo cultivadas no berço do ator racional, demonstram que o social penetra profundamente nesse self. Isso indica que os padrões e regras sociais, além de refletir padrões de pensamentos e ações, atingem o reino das emoções, conferindolhe forma e conteúdo, como salienta Hochschild (2003), um dos pilares da sociologia das emoções.

Embora tenha ganhado fórum próprio na sociologia, com a sociologia das emoções, essa instância permanece obscurecida, porque apesar desses autores entenderem a importância das instituições sociais e morais para a delimitação das emoções, como estudam Erving Goffman (1974), George Foster (1972), Robert Levy (1973), William Goode (1964) entre outros, há pouco entendimento sobre a importância das emoções na conformação da realidade moral, institucional e rotineira do "Mundo da Vida". As dimensões dessa instância são ainda subestimadas e visualizadas em termos funcionais e o foco recai sobre a atitude natural e não sobre o epoché. Em outras palavras, o movimento de abstenção do pensamento ante a constância do "espetáculo do mundo", como diria Husserl (1989), quando ocorre a produção de "distância em relação às validações naturais ingênuas" não são conhecidas, logo a propriedade autoadaptativa e recursiva do ego que possibilita o epoché, fundamentando a subjetividade, ainda carece de compreensão.

Logo, para compreendermos a relação entre memória social e subjetividade, se faz necessário reavaliar a precedência ontológica entre razão e emoção no plano das consciências individuais. Afinal, essa assunção que sustenta grande parte da teoria sociológica é o que teria sustentado a expectativa da universalização da racionalidade e das identidades na gnosiologia moderna. No entanto, como essa perspectiva se mostrara falaciosa pela inegável pluralidade da atualidade, julgo ser pertinente ampliarmos o escopo de análise sobre a subjetividade humana, o que requer uma avaliação transdisciplinar sobre o papel do corpo, do prazer, dos afetos, da família e de demais instituições na construção dessa entidade biopsiquicossocial.

A proposta desse artigo, portanto, é colocar em segundo plano alguns dos pilares filosóficos que sustentam as discussões sociológicas sobre a relação entre subjetividade e estrutura social, e lançar mão de outras estratégias para pensarmos tal problema, como a transdisciplinaridade. Então, diante desse antigo embate sociológico, proponho explorar a hipótese de que é na constituição do self que encontramos o potencial de objetivação e transgressão 
1 A neurociência tem ganhado grande destaque nos últimos anos, sua evolução permite, por meio de neuroimagens, registrar com grande precisão as regiões anatômicas cerebrais que atuam no momento mesmo em que se deflagram ações, pensamentos e sentimentos, do maior circuito até a sinapse no minúsculo espaço entre os neurônios. O intuito dessa área do saber era justamente conectar as compreensões da psicologia com a neurobiologia. A neurociência cognitiva, por exemplo, passa a se ocupar com as bases neuronais das funções cognitivas como a percepção, a memória e a atenção como Posner \& Digirolamo (2000) ou, ainda, Antônio Damásio (1999). Mais tarde inserem as emoções e os sentimentos na neurociência afetiva com Pankseep (1998) e Joseph LeDoux (1996). Alguns estudiosos da atualidade tem se preocupado com a base neuronal da motivação social, ultrapassando as necessidades vitais como fome, sede e sexo (HILGARD, 1980). Logo, essa área que teve como impulso vincular socioneuropsicologia cognitiva como Kihlstrom \& Klein (2002), se transformou em uma neurociência social cognitiva com Blakemore, Winston, \& Frith (2004), também Macrae, Moran, Heatherton, Banfield, \& Kelley (2004) e Lieberman, Ochsner, Gilbert, \& Schacter (2001); atualmente constitui a neurociência social com Cacioppo, Visser, \& Pickett (2006), das estruturas sociais, e também de construção de identidades, tanto pessoais, quanto sociais.

\section{Da metafísica à nanofísica: o corpo e a transdisciplinaridade}

Para tornarmos o self um objeto de estudo científico, atendendo a demanda da corrente positivista, se faz necessário estranhar a ideia de que o self, assim como sua subjetividade imanente, esteja atribuído apenas a um ego transcendental intangível. Também busco revisar a prerrogativa de que a origem de manifestação e atividade desse ego transcendental seja o critério de autenticidade do self e, portanto, das identidades.

Essas asseverações têm raízes modernas, fundadas na concepção cartesiana de existência, que tende a confundir tal sujeito transcendental com o próprio conhecimento (cogito), sem admitir que tal capacidade reflexiva humana apenas se realiza com um movimento inicial do ego transcendental em busca da matéria, como defendem os materialistas. Se admitirmos esse argumento, então, é possível assumir que tal ego possui precedência ontológica em relação ao cogito, e que, por isso, talvez não haja justificativa para dualização hierárquica entre razão e emoção, reflexão e vivência, indivíduo e sociedade.

A ocultação dessa entidade pré-cogito, que fundamenta o self, além das dualidades, sustenta uma concepção altamente individualizada de indivíduo e de cognição, como se conseguíssemos encontrar em nós mesmos coerência e integridade entre consciência individual, interesses e ações, a revelia de nossas emoções e da sociedade que nos circunda. As dimensões social e emocional, portanto, são constantemente ignoradas na constituição desse self.

Apesar dos pilares rigidamente estabelecidos para a compreensão da subjetividade, seus contornos permanecem desconhecidos, já que as emoções, vistas enquanto inferiores ao cogito e/ou desvios do ego, pouco palpáveis e relevantes, são insuficientemente trabalhadas pelo arcabouço científico. No entanto, recentes tecnologias abrem prerrogativas para pensarmos as emoções não apenas em termos metafísicos, como tradicionalmente tratam as ciências humanas, mas também físicos. A neurociência ${ }^{1}$ em suas diversas disciplinas, por meio de estudos de neuroimagem, demonstra como as emoções estão inscritas de forma objetiva no cérebro humano, sendo mobilizada a partir do social, como já apontava o pós-estruturalismo de Foucault (1979), que indica o corpo como microfísica do conhecimento.

Assim, como salientam vários sociólogos contemporâneos, como Goffman (1974), Elias (1994) e Bourdieu (1989), a neurociência também advoga que o pertencimento social possui fundamental importância para o funcionamento individual, tanto cognitivo quanto emocional, já que os humanos são seres adaptados para a sobrevivência dentro do contexto de um grupo e não fora dele, como demonstra o arqueólogo Steven Mithen 
que visa utilizar o conhecimento sobre o funcionamento do cérebro para melhorar o comportamento social dos pacientes. Todas essas áreas do saber se amparam na constatação da plasticidade cerebral, inicialmente observada em pacientes com lesões cerebrais, e agora também estendidas às pessoas que apresentam dificuldades de aprendizagem, de organização, de controle emocional, de planejamento, quando são aplicadas as técnicas de neurofeedback, coaching, entre outros.

2 O lobo frontal e pré-frontal, do neocórtex, seriam responsáveis pelas funções executivas, que permitem ao indivíduo tomar decisões, estabelecer objetivos, elaborar estratégias e planos para alcançar essas metas, estão relacionadas com o domínio da atenção, da racionalidade, com a capacidade de resolução de problemas, que possibilita o controle de interferir na inibição e na integração de constrangimento entre tempo e espaço. Entendo que o desenvolvimento do córtex pré-frontal e o estabelecimento de conexões plásticas com o sistema límbico, por meio do sistema de recompensa e outros circuitos neuronais, que possibilitam a atuação dos neurônios espelhos (FERRARI, GALLESE, et al., 2003), demarcam a possibilidade humana de apresentar um habitus, como já indicava Aristóteles, Tomás de Aquino, Weber, Durkheim e, contemporaneamente, Elias (1994) e Bourdieu (1989).

Dossiê Multimodalidade da Memória: Narrativa e Teoria Social

Arquivos do CMD, Volume 4, N.1. Jan/Jun 2016
(2003) ao revisar a genealogia humana. Seria essa imanente necessidade social a responsável pela deflagração da identidade, que só se torna possível, a partir de um sistema classificatório que se realiza a partir do embate com "o outro", ou seja, com a diferença, com algo fora de mim. Isso implica dizer que, no caso humano, o conhecimento ocorre apenas em um contexto moral, quando as emoções são despertadas pela efervescência coletiva durante as vivências, quando se delimitam as trajetórias individuais.

$\mathrm{Na}$ esteira de alguns neurocientistas como Damasio (1999) e LeDoux (1996), tal constatação nos permite admitir, por exemplo, a existência filogenética de disposições sociais que compõem nosso ego transcendental, como a empatia e a capacidade de cuidar de "outro", que estariam no cerne de regulação das nossas prioridades individuais e sociais, ou seja, de nossa memória, bem como das intenções, interesses e mesmo da cognição. A vida social, portanto, faria parte da autopoiesis dos seres humanos, como indica o neurobiólogo Maturana (1977), num complexo cálculo não-linear de sobrevivência, agenciado por complexos sistemas mentais, que atuam entre nosso sistema cognitivo, - representado fisiologicamente pelo córtex préfrontal $^{2}$, - e nosso sistema volitivo, - representado fisiologicamente pelo sistema límbico ${ }^{3}$, - especialmente pela atuação do hipocampo e da amigdala.
Isso significa dizer que os seres humanos produzem a si próprios, por meio de seus processos epigenéticos ${ }^{4}$ à medida que 0 embate social e ambiental acontece. Sua gênese ocorre a partir de uma rede fechada de produções e processos moleculares, em que as moléculas produzidas geram com suas interações a mesma rede de moléculas que as produziu, imputando uma recursividade do corpo. Esse sistema autônomo está constantemente se autoproduzindo, autorregulando e sempre mantendo interações com o meio e os demais seres, que desencadeiam no indivíduo mudanças epigenéticas determinadas. No caso dos humanos, a vida social seria uma das principais patrocinadoras dos processos recursivos, no momento em que o social é o principal catalisador dos processos miméticos.

Em outras palavras, é o desenvolvimento do córtex préfrontal e o estabelecimento de conexões plásticas com o sistema límbico, por meio do sistema de recompensa ${ }^{5}$ e outros circuitos neuronais, que possibilitam a atuação dos neurônios espelhos ${ }^{6}$. Esses neurônios possibilitam que a mimesis humana se deflagre, ou seja, a partir da observação das ações alheias, o cérebro não só copia a ação como a redireciona para a parte motora cerebral, que é fixada na memória como se o observador estivesse executando a ação observada, gerando um sistema de classificações. Essa associação mental permite modular a atenção, a racionalidade, gerando a capacidade de resolução de problemas, de ética e de sociabilidade, representam a inteligência social nos humanos, 
${ }^{3} \mathrm{O}$ sistema límbico constitui-se como uma síntese das descobertas de Franz Joseph Gall (1758-1828), Paul Broca, (1824-1880) e Papez, que culminaram no Sistema Límbico Profundo S.L.P.), é o que permite a sensação, percepção, afeto, motivação, memória de longo tempo, estabelece, portanto o tom emocional da mente, filtra os eventos externos através dos estados internos, rotula eventos como internamente importantes, permite o armazenamento de lembranças carregadas de emoções, modula a motivação, o impulso, a fome, $o$ sono, o cheiro, a alegria, a raiva, também ajuda a promover ligações e contatos sociais, além de modular a libido. Seria ainda composto pelo que McLean chama de Complexo R, ou cérebro arcaico ou basal, que seria relativo ao cérebro dos répteis, por isso, também pode ser chamado de Formação Reptiliana, constituído apenas pela medula espinhal e pela parte basal do telencéfalo. Conforme ressalta Carl Sagan (1987), em “Os Dragões do Éden”, o Complexo $\mathrm{R}$ ou arquicortex desempenha importante papel para o indivíduo, seria responsável por aquilo que Freud (1996) chama de pulsões, atuando no comportamento agressivo (pelo envolvimento do núcleo amigdalóide ou amígdala), na demarcação territorial, nas práticas ritualísticas (de acasalamento, por exemplo) e no estabelecimento da hierarquia social. O desenvolvimento do complexo amigdalóide e hipocampal (estruturas límbicas) permitem o surgimento das estruturas olfatórias, possibilitando o surgimento da primeira memória que é olfativa, e que permitiu que esses animais pudessem assim identificar nutrientes, elementos venenosos, parceiros sexuais, presas e predadores. também chamadas de funções executivas. Essa é a dimensão que permite ao indivíduo tomar decisões, estabelecer objetivos, elaborar estratégias e planos para alcançar essas metas, além do controle de interferir na inibição e na integração entre tempo e espaço. Seria essa conexão o propulsor da organização das informações que serão guardadas, absorvidas, descartadas ou ignoradas, entre outras possibilidades.

Esses movimentos fisiológicos do sínolo são candidatos mais concretos para a mônada psíquica pré-cogito, do que a metafísica, descrita pela filosofia e ciência humanista. A complexibilização das interações epigenéticas e genéticas acumuladas ao longo da evolução humana teriam levado ao desenvolvimento de uma fluidez cognitiva, como nomeia o arqueólogo Setven Mithen (2003), mas que refletem, na realidade, a arquitetura de conexões neuronais sinápticas entre os diversos módulos cerebrais $^{7}$, que alimentam e satisfazem-se pelas interações sociais e ambientais na medida em que ocorre $o$ desenvolvimento ontogenético de cada indivíduo.

Assim, as interconexões entre os múltiplos sentidos, que mobilizam emoção e razão, inconsciência e consciência, são orientadas por meio de como os sentimentos são atravessados pelos pensamentos, e de como os pensamentos são permeados pelos sentimentos, e estes acontecem a partir dos e nos processos volitivos. Tal volição só ocorre quando conexões sinápticas entre o sistema Límbico e o córtex frontal se deflagram no cérebro, por meio da produção de neurotransmissores que as habilitam. Logo, o pensamento é gerado, em grande medida, por esse movimento epigenético recursivo, que nós traduzimos como motivação. Não é à toa que as palavras "motivação" e "emoção" têm a mesma origem latina: movere ou "mover", implicando, portanto, necessariamente, atividade, força e energia como uma mônada.

Essa vontade não acontece na ausência de relações sociais que a potencializem, sendo a vontade inicialmente social e interpsicológica, para, aos poucos, tomar a dimensão intrapsicológica. Na análise de Molon (2003) sobre Vygotski, “o sentimento, o pensamento e a vontade - que formam a tríplice natureza social da consciência - são historicamente constituídos no contexto ideológico, psicológico e cultural, considerando o biologicamente constituído" (p. 94). As necessidades despertadas socialmente se integram entre si, formando os "motivos", e cada motivo é uma combinação particular de sentidos subjetivos, organizados nas mais diversas áreas de atividade humana (GONZÁLEZ REY, 2000).

Por outro lado, como afirmam Oliveira e Rego (2003), a afetividade humana também se constitui na relação com vários outros componentes psicológicos e intelectuais. Assim, para poder emocionar-se, motivar-se, o indivíduo humano precisa ter também memória, pensamento, imaginação, planejamento, conhecimento, linguagem, conceitos, significados, sentidos, percepção, atenção, atividades próprias ao córtex pré-frontal, que 
${ }^{4}$ Epigênese é o processo molecular e celular que governa a função dos genes, ocorre em uma escala nanométrica. Esses processos incluem metilação do DNA, mudanças na estrutura da cromatina, RNA não codificador e edição do RNA. Ver: Mehler MF. "Epigenetics and the nervous system". Annals of Neurology 2008;64(6):602-617; ou Szyf M, McGowan P, Meaney MJ. "The social environment and the epigenome". Environmental \& Molecular Mutagenesis 2008:49(1):46-60; ou Fabian MR, Mathonnet G, Sundermeier T, Mathys H, Zipprich JT, Svitkin YV, Rivas F, Jinek M, Wohlschlegel J, Doudna JA, Chen CY, Shyu AB. Yates JR 3rd. Hannon GJ. Filipowicz W. Duchaine TF. Sonenberg N. "Mammalian miRNA RISC recruits CAF1 and PABP to affect PABPdependent deadenylation". Molecular Cell 2009;35(6), P.868-880. As mudanças epigenéticas na função neural afetam os circuitos neurobiológicos que influenciam a saúde (física e mental) comportamento e a aprendizagem. Os efeitos da epigênese sobre a função dos genes têm início na concepção, e prosseguem durante o desenvolvimento intrauterino e no desenvolvimento pósnatal. Em consequência desses estudos, há um interesse crescente sobre a forma pela qual a epigênese pode ser um fator da esquizofrenia, de distúrbios bipolares e de condicões tais como 0 se alimenta do Sistema Límbico pelo circuito de recompensa, mas que não é ativado sem o embate social, sem o contato com o outro. Seria nessa complexa configuração que a diferenciação, que marca a individualização, e a assimilação à consciência coletiva são delineadas.

Então, tais conjuntos de funções mentais gerenciados pelo sistema volitivo demarcam a possibilidade humana de apresentar um habitus, como já indicava Aristóteles, Tomás de Aquino, Weber, Durkheim e que contemporaneamente fora reelaborado por Elias (1994) e por Bourdieu (1989). Afinal, é pela mimesis que as pulsões e sentimentos se tornam ativas, passando de diathesis (disposições passivas) para hexis - o habitus, em latim, que indicam disposições ativas ou estados ou possessões; em inglês, "having", significa propriamente saber algo que não será esquecido. Desse modo, a associação entre representações sensoriais e motoras é contingencial, uma representação é preditiva da outra, e não só integradas no tempo e espaço.

A ativação dessa complexa configuração mental indica uma inteligência social, como é entendido por Bourdieu (1983), como [...] um sistema de disposições duráveis e transponíveis que, integrando todas as experiências passadas, funciona a cada momento como uma matriz de percepções, de apreciações e de ações - e torna possível a realização de tarefas infinitamente diferenciadas, graças às transferências analógicas de esquemas [...] (p. 65), seria, "o lado ativo do conhecimento prático que a tradição materialista, sobretudo com a teoria do reflexo tinha abandonado". (p. 61). Esse saber incorporado, é, portanto, “...o produto de um trabalho social de nominação e de inculcação ao término do qual uma identidade social instituída por uma dessas 'linhas de demarcação mística', conhecidas e reconhecidas por todos, que o mundo social desenha, inscreve-se em uma natureza biológica e se torna um habitus, lei social incorporada" (p. 66). São essas diposições internalizadas que condicionam as habilidades, interesses e prioridades do indivíduo, porque desperta neles um senso prático de classificações de percepções, que orienta como substituir ou reacomodar as aquisições mais novas pelas mais antigas.

Assim, durante o desenvolvimento ontogenético, quando ocorrem os processos de socialização, as conexões entre os sistemas mentais, objetivadas especialmente pelo circuito de recompensa, são desenvolvidas seguindo tanto processos naturais ${ }^{8}$ e recursivos, quanto históricos de maturação cognitiva, que vão influenciar a incorporação de habilidades e saberes, bem como a eleição de prioridades e interesses. Logo, a constituição do self ocorre tanto pelo embate psicogenético, quanto pelo sociogenético advindos das configurações de longa duração às quais os indivíduos estão expostos, como já alertava Elias (1994). A consciência seria, portanto, indissociável da moral e dos afetos desenvolvidos ao longo das trajetórias individuais, para a formação das identidades tanto individuais, quanto sociais. 

adulta.ver: Mill J, Petronis A. "Preand peri-natal environmental risks for attention-deficit hyperactivity disorder (ADHD): the potential role of epigenetic processes in mediating susceptibility". The Journal of Child Psychology and Psychiatry
Psychility 2008;49(10), p.1020-1030

${ }^{5} \mathrm{O}$ sistema de recompensa atua dentro do sistema límbico. O circuito começa com a área tegmentar ventral, situada na região cinzenta do tronco cerebral, a partir daí, os impulsos elétricos atingem o núcleo de accubens, seguindo para o córtex pré-frontal. Esse seria o caminho da dopamina, onde correm também a noradrenalina e o cortisol, por isso, a ativação dessa conexão neuronal possibilita o prazer e levam a repetidas tentativas de estimulação, como ocorre com o prazer sexual, alimentar, o uso de drogas, o engajamento em conflitos, ou atividades esportivas radicais, ou violentas, entre outros.

6 Os neurônios-espelho foram descobertos em 1997 por três neurocientistas da Universidade de Parma, na Itália: Giacomo Rizzolatti, Vittorio Gallese e Leonardo Fogassi (2003). Depois, outros pesquisadores aderiram, como o neurocientista cognitivo Vilayanur Ramachandran, da Universidade da Califórnia de San

O mercado, o consumo e a mídia, além da família, da religião e da escola, se mostram como instâncias mediadoras das disposições internalizadas, porque mobilizam as práticas individuais e atuam no sistema mimético humano, pelo seu potencial estético, volitivo e marcador de linguagem, de diferenças e de distinções sociais. Tais instituições se tornam fundamentais na produção da agência humana, porque a habilidade mimética individual estaria mais aberta à programação durante a infância, quando a recursividade do corpo está sendo esculpida e delineada, gerando disposições fundamentais para a agência do indivíduo.

\section{Illusio, poder e reconhecimento}

$\mathrm{Na}$ perspectiva aqui desenvolvida, o indivíduo adquiriria identidade apenas no contexto de um grupo social, a partir do embate com o "outro" e das dinâmicas de reconhecimento em relação às suas características, gostos, ações e desejos. Isso porque a entrada no mundo social implica que o agente deva abandonar a fantasia originária e introspecta de centralidade narcísica, o que não ocorre sem motivação, incorporando à consciência individual (ao ego pré-cogito) à consciência coletiva (a moral e o conhecimento), tornando possível o reconhecimento da alteridade, do outro. Esse abandono da introspecção do ego em prol do conhecimento e do outro, é o que permite a ele se objetivar e adquirir identidades, mas tal movimento não ocorreria sem motivação.

Como salienta Elias (1994), o sentido que cada um tem de sua identidade está estreitamente relacionado com as relações de 'nós e de eles' no nosso próprio grupo e com a nossa posição dentro dessas unidades que designamos "nós e eles'. É o reconhecimento dessa posição que mobiliza a atenção necessária para a incorporação das diretrizes grupais. Assim, o afastamento motivado de um "eu" em direção a um "nós" e o reconhecimento da posição almejada e/ou alcançada são justamente o processo de formação do self, ou seja, quando a identidade tanto individual, quanto social do indivíduo são delineadas.

A relacionalidade entre identidade e diferença associa-se à sua capacidade de autorreferenciação, de modo que uma fornece as condições para que a outra exista, sendo a identidade marcada pela diferença. E é nesse sentido que o reconhecimento social se torna primordial, uma vez que atua como marcador de prioridades e interesses, ao legitimar determinadas práticas, mobilizando e motivando a atenção dos indivíduos ao mundo externo. Assim, para que a diferença seja processada, comparada, calculada, inculcada é preciso a atenção a um estímulo inicial e o armazenamento da representação desse estímulo na memória, até que seja encontrada novamente (RENSINK, 2000). Qualquer fator que interfira na manutenção dessa representação, como um estigma, como avalia Goffman (1988), ou falta de reconhecimento 
Diego. A descoberta ocorreu ao observarem um primata com eletrodos ligados a neurônios individuais no córtex pré-motor, para estudar sua atividade neural ao estender a mão para pegar diferentes objetos. Vendo Fogassi casualmente pegar uma uva passa, os neurônios pré-motores do animal dispararam como se ele próprio a estivesse pegando. $\mathrm{O}$ macaco não $\mathrm{o}$ imitou, mas o movimento foi registrado em seu cérebro como se fosse dele na mesma região em que é feita a centralização do movimento no cientista. Como nos interessa aqui o ser humano, o que descobrem é que não só imitamos como também, se estivermos olhando ou ouvindo as ações de outra pessoa, nosso cérebro funciona como se estivéssemos fazendo aquelas ações. E mais, que a compreensão dos acontecimentos, dos movimentos, se dá, primeiro, através desses neurônios. $\mathrm{Se}$ estivermos assistindo um atleta fazendo algo que não fazemos, para nossos cérebros é como se o estivéssemos fazendo. Ou seja, aprende-se aquilo do ponto de vista cerebral, e não corporal. Veja: DOBBS, David. Reflexo Revelador. "Mente \& Cérebro". Scientific American Brasil: ano xiv, nº161, 2006. p. 46-51. Trad: Júlio de Oliveira

$\mathrm{Na}$ visão vertical do cérebro defendida pela genética e pelos modularistas, como Jerry Fodor (1983), Gardner (2000) Cosmides e Tobias (1987), Karmiloff-Smith (1995), as identitário ou ainda um falso reconhecimento, como alerta Taylor (1998), altera as possibilidades cognitivas sobre aquela informação. Isso porque as emoções despertadas durante o embate social facilitam ou perturbam a captação automática da atenção (WENTURA, ROTHERMUND e BAK, 2000). Logo, a diferença possibilita distinguir os signos e as representações que compõem minha identidade à medida que alimenta o repertório de disposições miméticas de cada indivíduo.

Desse modo, tanto as diferenças quanto as identidades são construídas por relações de poder transparentes no reconhecimento social, que fixam e disputam determinados saberes, enquanto desestabilizam e descartam outros. Logo, tais norteadores não são dados e acabados, são os construtos de uma linguagem específica, embora vacilante, de determinado contexto cultural e social, que suporta maleabilidade diante de seu caráter instável e cambiante. Diante dessa abertura em relação a seu conteúdo, qualquer grau de fixação de identidades e de diferenças perdura na mesma medida em que há espaço para a representação, uma vez que é nela que estas ganham sentido, se filiando à intrincada rede de saberes e poderes, que por sua vez definem e determinam identidade e diferença.

A autocategorização, portanto, é demasiado complexa, uma vez que a identidade-eu se constrói pelo afastamento de si, quando se adquirem disposições do grupo. Mas também pela diferenciação em relação ao grupo, ou aos grupos com os quais se tem contato durante as trajetórias individuais, pelo reconhecimento de sua posição dentro desse ou desses grupos. Nesse sentido, não existe um lócus original do self, composto de conteúdo autêntico, já que a aquisição de substância é inaugurada, construída e mantida mediante o contato com o "outro", sendo que a identidade-eu e a identidade-nós não se estabelecem de uma vez por todas, mas está sujeita a transformações constantes muito específicas relativas ao ambiente e à aprendizagem social, como já alertara Elias (1994).

No entanto, de acordo com a maturação cognitiva do indivíduo, as primeiras disposições do grupo incorporadas se estabelecem mais arraigadamente constituindo o self de forma ontológica e normativa, daí a sensação de existir uma essência fundamental do ego, mas é preciso salientar que este conteúdo é adquirido num meio moral, sendo, portanto, contingencial. Como indica Elias (1994), portanto, a experiência de si e, consequentemente, a individualização são parte do processo social pelo qual passam as configurações, isso porque a psique ${ }^{9}$ do indivíduo, após o processo de socialização, deve substituir seus próprios objetos de investimento por outros suportados pelas instituições sociais, em que o público, a coletividade, o social constantemente invade e constitui o privado, o individual, o agente. Nesse processo de socialização, o agente se torna capaz de elaborar representações sociais que são para ele fonte de prazer e que, por isso, ativam o sistema de recompensa, modulando a atenção, possibilitando a produção de um habitus; caso contrário, 
as faculdades, módulos, ou inteligências são capacidades fundamentais e não meramente qualidades psicológicas, por isso, podem ser identificadas a mecanismos cerebrais específicos, determinados geneticamente e encontram-se associadas a estruturas neurais associadas distintas, computacionalmente
autônomas. A tese aqui defendida visa superar essa visão vertical com um diálogo dos estudos da neurociência, que confirmam a visão da horizontalidade da mente, como na perspectiva associacionista, que também está presente em Piaget, admitindo atividades epigenéticas como fundamentais para $o$ curso evolutivo e para o desenvolvimento das habilidades intelectuais e motoras, admitindo, portanto, uma não linearidade e não rigidez de tal processo.

${ }^{8}$ Para Piaget (1994), a inteligência é uma adaptação a situações novas, quando ocorre a organização de ações e pensamentos, característico de cada fase do desenvolvimento do indivíduo, que ocorre em etapas ou estágios sucessivos, com complexidades crescentes, encadeadas umas às outras. Ele destaca três fases de desenvolvimento que vai do nascimento aos dois anos, depois dos 2 aos 7 anos, dos 7 aos 11 anos, dos 11 aos 16 anos. Recentes estudos (2002) demonstram que esse processo de maturação se relaciona ao crescimento cerebral e sináptico e se estende até os 25 anos de idade. Qualquer evento entrariam em estado de anomia e introspecção. Logo, as primeiras disposições incorporadas rotinizam esquemas corpóreos, pelos processos homeostáticos e metabólicos ${ }^{10}$, que coordenam a liberação de neurotransmissores, proporcionando a confecção epigenética de conexões sinápticas, que produzem os vínculos entre o sistema volitivo e o sistema cognitivo, imprimindo-lhe uma identidade epigenética, que será preditiva das demais.

Segundo Freud (1999), esses movimentos internos do corpo são sentidos por nós como emoções, e é fundamental salientar que esse corpo é movido pelo amor próprio, pelo sentimento de si mesmo e o sentimento do mundo. Logo, o prazer e o afeto, bem como o medo, sentidos durante a adaptação do corpo ao meio ecológico e sócio-simbólico, agenciam as conexões mentais que habilitam tanto a consciência, quanto a reflexividade do indivíduo, como afirma LeDoux (1996). Portanto, durante o contato social são programadas as motivações individuais, que se estabelecem a partir da classificação de alvos com os quais o agente se identifica e que são socialmente reconhecidos e sancionados. Assim, o pensamento e as fantasias se baseiam nos valores típicos de um momento sócio-histórico particular, mas que constituem um habitus originário e único, que se apresenta de forma ontológica, porque se torna indissociável da identidade pessoal do indivíduo, e de seu sistema volitivo.

O habitus originário se constitui, portanto, no processo de elaboração processual e incessante da sociedade, do coletivo, nos primórdios da maturação cognitiva do indivíduo, por meio da illusio, como já indicava Bourdieu (1989). A illusio seriam apostas, crenças, símbolos e fantasias subjetivas coletivamente sancionadas, calcadas em uma metafísica da distinção, que centraliza o indivíduo no mundo, via honra e dignidade, frente a nós mesmos e aos demais, habilitando seu reconhecimento e legitimando seu valor. Seriam tais motivações, valores e disposições internalizadas o que nos dá a sensação de normal, essencial e natural, embora tal autenticidade seja contingencial e varie de indivíduo para indivíduo e de grupo para grupo. Logo, a autocategorização ontológica, ou a identidade pessoal, não porta nenhum elemento objetivo que a torne essencial; são os valores tácitos atribuídos pelo indivíduo numa determinada configuração social que delimitam sua ontologia.

Nesse sentido, a instituição social mais provável de promoção de tais valores ontológicos na modernidade seria a família, primordialmente, e depois a escola, a religião e a mídia, pelo crescente espaço que tem ganhado na vida (infantil) dos indivíduos, quando os valores adquiridos se tornam sacros, como avalia Piaget (1984). Nessa direção, durante seu desenvolvimento, os seres humanos adquirem a aprendizagem dos conjuntos de símbolos sociais com seus correspondentes significados do conhecimento de seus antepassados, do qual adquirem e elaboram fantasias, imagens e símbolos aos quais se prendem, transformando-os nos princípios orientadores de sua conduta, 
traumático, abrupto poderia atrapalhar o desenvolvimento dessas etapas, levando a diversas possibilidades de respostas como avalia a psicanálise de Freud, por exemplo.

${ }^{9}$ A psique é a instância que intermedeia a relação entre o corpo e a estrutura social e nela se joga todo o mistério humano, pois media o fluxo de significantes da cultura simbólica e mítica com o substrato biológico inevitável e concreto, fazendo refluir um no outro em um contínuo processo de imbricamento, necessário e fundamental para todos os agentes humanos. Pela capacidade essencial de fazer surgirem representações (CASTORIADIS, 1982, p.324)

10 O ambiente interno do corpo é regulado pelo sistema endócrino, que atua nos processos homeostáticos e metabólicos, por meio de glândulas (hipófise, tiroide, paratireoides, suprarrenais, ovários, testículos etc.), que geram a produção e síntese de hormônios e neurotransmissores que operam em todas as unidades celulares. As mudanças ocorrem em um nível protoplasmática, a parte viva da célula se molda à medida que ocorre $o$ desenvolvimento, constituindo também a matriz extracelular dos órgãos e tecidos. É um sistema físico-químico de natureza coloidal e pode passar facilmente do estado sólido ao líquido. Os principais constituintes químicos do protoplasma são as proteínas (ácidos aminados, polipeptídeos etc.), os comportamento e identidade. Logo, a autocategorização é um processo transitivo e dialógico, já que se dá em conformidade com o outro. Portanto, qualquer concepção moral, temporal ou sobre a natureza e os bens é aprendida e apreendida de outros indivíduos, ou seja, socialmente.

Assim, a família, a escola e a mídia funcionariam como mercados simbólicos, ou instâncias de legitimação, espaços instituidores de competências necessárias aos agentes para atuarem nos diferentes espaços sociais, chamados por Bourdieu (1989) de campos. A reprodução moral, ou seja, a transmissão dos valores, virtudes e competências, maneira de ver o mundo, o mesmo mundo simbólico, serve invariavelmente de fundamento à filiação legítima dos habitus distintos e desiguais, fortalecendo $\mathrm{e}$ intensificando a hierarquia do culturalmente aceito ou execrável, do autêntico ou do inautêntico, porque o habitus encontra-se no princípio das afinidades imediatas que coordenam os encontros e as aquisições sociais. Assim, os saberes, o estilo, o bom gosto, o talento aparecem principalmente como frutos do acúmulo de capital cultural (Bourdieu, 2007), não como uma simples subjetividade, mas como uma "objetividade interiorizada" (Bourdieu, 1983), fruto da interação entre sociedade e indivíduo

A vida social é governada, portanto, pelos interesses do campo, mas no âmago do próprio sistema, sendo que há uma prioridade ontológica em relação ao patrimônio adquirido e interiorizado no organismo por meio da aprendizagem durante os primeiros contatos sociais que se faz com as instituições tradicionais e a cultura local. Isso porque tal aprendizagem que exige tempo e submissão a um processo de assimilação (ou cultivo) e interiorização por parte do indivíduo, se torna um estado incorporado. Para Elias (1994), essa interiorização das formas sociais pelos indivíduos, ou seja, as "características maleáveis da criança recém-nascida [que] se cristalizam, gradativamente, no contorno do adulto, nunca depende exclusivamente de sua constituição, mas sempre da natureza das relações entre ela e as outras pessoas”. O que significa dizer que após sua aquisição, o capital cultural passa a ser indissociável do indivíduo, constituindo seu capital simbólico.

Esse capital cultural também se manifesta enquanto um estado objetivado, por exemplo, pela aquisição de bens de consumo duráveis - livros, instrumentos, máquinas, quadros, discos, esculturas etc. Portanto, é tributário da aquisição de bens materiais e dependente do capital econômico. Para ser ativo, material e simbolicamente, deve ser utilizado, apreciado e estudado. Por fim, o capital cultural também pode se apresentar como um estado institucionalizado, que seria a forma objetivada da cultura, como certificados escolares, títulos e prêmios. Apesar de uma certidão de "competência cultural" não necessariamente indicar o real acúmulo de capital cultural indica o reconhecimento oficial de tal processo. O valor do certificado depende de sua 
carboidratos, os lipídios, as substâncias minerais e a água. $\mathrm{O}$ protoplasma é uma substância viva que tem a propriedade da assimilação e sofre suas consequiências (crescimento, divisão etc.). O protoplasma reage aos excitantes mecânicos, físicos e químicos; pode emitir pseudópodes e sofre atrações e repulsões.Existem três propriedades importantes dos protoplasmas no sistema nervoso: irritabilidade, condutibilidade e contratilidade

${ }^{11}$ No livro I de A Gaia Ciência, Nietzsche começa a esboçar seu pensamento sobre "a doutrina do sentimento de potência" e escreve, a partir de 1882, alguns fragmentos sob o título de vontade de poder. No entanto, é somente a partir de 1885 que o pensamento sobre a noção de vontade de poder ganhará importância capital para a última filosofia de Nietzsche como "ensaio de uma nova interpretação do mundo". raridade e permite a convertibilidade do capital cultural em capital econômico.

\section{Considerações Finais}

$\mathrm{Na}$ gnosiologia, aqui trabalhada, a consciência, a reflexividade e a moral não são o fundamento do indivíduo. Embora sejam tais faculdades as facilitadoras da produção de identidade, essa só se torna possível, na medida em que o agente se coloca em atividade e movimento. Tais atributos são propriedade fundamental do sistema volitivo humano, e que permite o embate com o outro. Essa volição do ego em busca do saber, da moral, do outro, da matéria, então, é o que constitui o centro fundamental da subjetividade individual. Desse modo, para compreender o ambiente atual de pluralidade identitária se faz fundamental observar como a moral mobiliza essa entidade individual para a produção de consciência e reflexividade nos indivíduos.

Isso porque, embora seja central para a produção das identidades, a volição humana é desprovida de conteúdo, daí sua característica introspectiva. Para aquisição de substância deve se afastar de si mesmo, o que significa dizer que a formação de identidade, portanto, se estabelece pela mobilização nanofísica (já que ocorre em escala nanométrica) da aprendizagem humana, numa pedagogia específica, que rotiniza esquemas corpóreos satisfazendo o sistema volitivo e pulsional de cada corpo. Essa vontade de potência ${ }^{11}$, como propusera Nietzsche (1979), que ontologicamente fundamenta as teias de significados humanos, por causa de seu potencial mimético, é o que possibilita aos indivíduos aprenderem e memorizarem, uma vez que tal sistema volitivo regula os critérios de sua atenção e motivação, que busca não só se manter em equilíbrio, mas também potencializar sua condição.

Essa metabiologia que busca o poder, como na versão de Nietzsche, outrora foi o que a filosofia pressupusera como atributo metafísico que impele o humano ao conhecimento e que, no racionalismo moderno, passara a se pautar numa metafísica da subjetividade, cujo conhecimento seria construído por meio das relações que os sujeitos constroem com seus sentidos, sendo suas representações as funções de tais dados elementares. Naquele momento, alimentados por essa crença, estimularam o deslocamento da socialização para a racionalização, antes exclusiva às instituições tradicionais, como a família e a religião. A influência do estado, da ciência e da economia ampliou o universo de padrões normativos e culturais, afetando as competências subjetivas, especialmente pelo mercado de trabalho, quando ocorreu a objetivação das técnicas. Tal advento possibilitou o estabelecimento do utilitarismo, ou, como nomeia Totaro (2010), de um tipo de cultura do cálculo.

Muitos positivistas estimulados por essa visão solipsista de indivíduo, apesar de terem expurgado a metafísica, não 
conseguiram explicar a natureza da supremacia da razão diante da irredutível pluralidade de modos de vida, especialmente por meio dos ditos selvagens. Incorriam sempre num realismo aristotélico, que identificava na matéria, no mundo externo, a essência da verdade. Esse pressuposto acabou levando ao questionamento sobre a essência humana (Ursprung/origem) diante da diversidade irreversível de consciências frente a um mesmo mundo material, uma vez que ignoravam as influências ontológicas desenvolvidas no seio familiar e tradicional. Haveria de ter algum motivo biológico para tais diferenças, uma vez que os indivíduos estão expostos a um mesmo universo material e simbólico ofertados pelo Estado. Tamanha era essa crença na experiência, que acabou fundamentando o evolucionismo social e a crença da diversidade de "raças" (Herkunft/ procedência), para a explicação das diferenças culturais, que na realidade expressavam as relações de poder travadas entre os povos, que, de acordo com sua posição, se associavam aos rótulos vigentes para delimitar a hierarquia do poder, ou se era primitivo ou civilizado (Entestehung/emergência).

Como advogo aqui, para além desses pressupostos metafísicos, o que conduz o homem ao conhecimento, e consequentemente ao poder, seria microfisicamente localizado, como indicara Foucault (1979), herdeiro do método genealógico de Nietzsche. Isso porque esse self seria estabelecido numa dialética histórica, uma vez que o conhecimento adquirido pelo trabalho, pelo consumo, pela escola, pelo Estado, pela religião e pela família, delimita a posição (pelos capitais adquiridos) e a consciência desse indivíduo sobre sua posição na estrutura social, como propõe Pierre Bourdieu (1989). Logo, todas essas instituições regulam as possibilidades e os acessos ao saber e ao poder, ambos tidos como estruturais na consolidação da estrutura social. No entanto, há uma hierarquia na produção ontológica do sujeito, exercida pela família primordialmente, e em muitos casos pela religião, uma vez que estas habilitam o habitus originário do indivíduo, pela mobilização afetiva de sua mônada psíquica, pela illusio.

Logo, a base orgânica que formaliza a vontade de potência é operada sob regras nanofísiológicas, num contexto moral e histórico, habilitando racionalidades próprias, de acordo com as diretrizes mimetizadas ao longo da trajetória de cada indivíduo. E como tal, esse processo de subjetivação teria validade fora de um quadro descritivo metafísico e/ou aristotélico, já que a lógica desse se baseia em trocas simétricas, em dualidades, enquanto que a lógica da subjetividade extrapola essa medida, sendo, portanto, a antítese da verdade e da mentira, do negativo e do positivo, embora os incluam em seu complexo sistema. Ou seja, a identidade seria uma integração da objetividade e da subjetividade, em que a causalidade do contexto objetivo do universo recebe um retorno por meio da subjetividade trazida de volta ao ambiente. Esse retorno, no entanto, se mostra deveras complexo em relação às respostas do mundo físico, mas pressupõe-se que seja um tipo 
12 Muitas regiões que compõem sistema límbico são responsáveis em modular a visão. A amígdala, por exemplo, é responsável pela associação da imagem a um sentido afetivo, o que auxilia na percepção de situações perigosas. A porção frontal do giro cingulado coordena odores, visões com memórias agradáveis de emoções anteriores. O tálamo recebe informação sensorial dos olhos e ouvidos e transmite à área do cérebro que lida com esse específico dado sensorial. de causalidade induzida por imagens ${ }^{12}$. A subjetividade seria, portanto, cibernética e não meramente dual.

Essa diferença, entre a cognição e a volição, teria sido responsável pelo rebaixamento das emoções a um poder indeterminado ao contrário do nexo do universo físico, plausível de classificação. Isso não significa, no entanto, que a subjetividade seja indeterminável, significa apenas que a sua base volitiva difere de forma estrutural dos eventos frutos de causalidades irreflexivas e físicas dos objetos. Em outras palavras, a transferência da causalidade do objeto para o mecanismo da subjetividade adiciona tanta riqueza estrutural ao nexo causal, que ele aparenta ser uma nova força emergente, ulteriormente diferente dos mecanismos de determinismos que conectam todos os objetos juntos. Seria essa complexidade que ofusca a compreensão da subjetividade.

Portanto, seria essa entidade volitiva a propositora de todas as ações e os pensamentos, que inaugura a subjetividade e funda a identidade, os gostos, os desejos, as pulsões, a cognição, a emoção, a consciência, a memória, a cultura, portanto, de toda agência humana. Essa constatação que transborda o arcabouço e a metodologia racionalista requer que ampliemos as possibilidades de apreensão das verdades para que incluam também a compreensão dessa instância reguladora de subjetividades, enquanto motor da e para a percepção da realidade.

Desse modo, rejeitamos o pressuposto racionalista, de que as instâncias cognitivas, que habilitam a consciência e a reflexividade, teriam precedência sobre as emoções, em que a autoestima seria um cálculo maximizador do embate entre essas faculdades mentais. As teorias que se sustentam por esse ideal racionalista, não conseguem explicar situações em que os indivíduos sustentam identidades sociais que levam a autoestimas ou status negativos, mesmo quando poderiam escolher outras identidades sociais. Tampouco explicam os movimentos identitários que passam a reivindicar espaços de vocalização para seus interesses identitários, como tem ocorrido a partir da metade do século XX. Isso porque as identidades sociais derivam de uma tensão entre necessidades humanas por reconhecimento e similaridade com outros, por um lado, e, por outro, necessidade por unicidade e individuação.

Essa relação similaridade e não-similaridade aqui não é entendida enquanto contradição do ego, que está tanto habilitado para o reconhecimento, quanto para a diferenciação. Isso porque, como vimos, por trás da ilusão do cálculo reflexivo em relação a uma identidade social, está um cálculo inconsciente do ego, que seria anterior ao conhecimento e mesmo à moral, e, por isso, teria autonomia em relação à reflexão, mais que isso, seria uma condição sine qua non para a aquisição de conhecimento e de consciência para si. Tal cálculo seria sentido por nós como emoções.

Esse ego, que coloca o indivíduo em atividade e movimento, como uma mônada psíquica, teria, portanto, uma 
prioridade ontológica sobre a reflexão e mesmo sobre a cognição. Seu caráter abstrato e subjetivo, pouco palpável e concreto, perturba e distorce a presença positiva e afirmativa imanente tanto da moral quanto da materialidade (consciência em si), promovendo uma objetividade sempre incompleta, já que, nessa busca incessante do ego de desejar ser, não há uma concordância entre desejo e fato (moral). Seria essa incompletude a marca da humanidade, que é constituída de sujeitos que estão sempre além de si mesmos, em um movimento de transcendência constante que se faz dialético.

\section{Referências Bibliográficas}

ADORNO, T.; HORKHEIMER, M. Dialética do Esclarecimento. Rio do Janeiro: Zahar, 1995.

ARISTÓTELES. Poética. Porto Alegre: Globo, 1996.

BACHELARD, G. "A poética do espaço". In: Os Pensadores. São Paulo : Abril Cultural, 1978

BARTLETT, F. Remembering: a study in experimental and social psychology. Cambridge: Cambridge University Press, 1961.

BENJAMIN, W. A Obra de Arte na Época de sua Reprodutibilidade Técnica. In: (ORG), Magia e Técnica, Arte e Política - Obras escolhidas. São Paulo: Brasiliense, 1985.

BENJAMIN, W. "On the Mimetic Faculty" In: Reflections. New York: Schocken, 1986. p. 333-336.

BLAKEMORE, S.; WINSTON, J.; FRITH, U. "Social cognitive neuroscience:where are we heading?". Trends Cogn. Sci. 8, p. 215-222, 2004.

BLUMER, H. Symbolic interactionism - Perspective and method. New Jersey: Prentice-Hall, 1969.
BOURDIEU, P. O Poder Simbólico. Rio de Janeiro: Bertrand, 1989

CACIOPPO, J.; VISSER, P.; PICKETT, C. Social Neuroscience: people thinking about people. Cambridge: MIT Press , 2006.

CASSIRER, E. Ensaio sobre o homem: introdução a uma filosofia da cultura humana. São Paulo : Martins Fontes, 2001.

COSMIDES, L.; TOOBY, J. "From evolution to behaviour: evolutionary psychology as the missing link" In: DUPRÉ, J. The latest on teh best: Essays on Evolution an Optimality. Cambridge: Cambridge University Press, 1987. p. 277-306.

DAMÁSIO, A. O Sentimento de Si: o corpo, a emoção e a neurobiologia da consciência. Publicações Europa-América: Mem Martins, 1999.

DEWEY, J. Como Pensamos. São Paulo: Editora Nacional, 1959.

ELIAS, N. O Processo Civilizador: uma história dos costumes. Vol I. Rio de Janeiro: Jorge Zahar Editor , 1994.

FERRARI, P. et al. "Mirror neurons responding to the observation of ingestive and communicative mouth actions in the monkey ventral premotor cortex". Eur. J. Neurosci, 17, v. 17, p. 1703-14, 2003.

FODOR, J. The Modularity of Mind. Cambridge (Mass): The MIT Press, 1983.

FOSTER, G. M. "The anatomy of envy". Current Anthropology, 13, 1972. 165-202.

FOUCAULT, M. Microfísica do poder. Rio de Janeiro: Edições Graal, 1979.

FOUCAULT, M. Vigiar e Punir: nascimento da prisão. $36^{\mathrm{a}}$ ed. ed. Petrópolis, RJ: Vozes, 2009.

FREUD, S. "Formulações sobre os dois princípios do funcionamento mental" In:

S. Freud, Obras Completas (Vol XII; J. Salomão, trad.). Rio de Janeiro: Imago, 1996.

GARDNER, H. Inteligências Múltiplas - A Teoria na Prática. Porto Alegre: Artmed, 2000.

GOFFMAN, E. Estigma: notas sobre a manipulação da identidade deteriorada. Rio de Janeiro : LTC, 1988.

GOFMAN, E. A Representação do Eu na Vida Cotidiana. Petrópolis: Ed. Vozes, 1974. 
GONZÁLEZ REY, F. L. "La investigación sobre la subjetividad humana: algunas cuestiones para el debate". Anais do I Simpósio Multidisciplinar Pensar, Criar e Transformar. São Paulo: Unimarco Editora, 2000.

GOODE, W. "The Theoretical Importance of Love" In: COSER, R. The Family. New York: St. Martin's Press, 1964. p. 143-56.

HILGARD, E. R. "The trilogy of mind: Cognition, affection, and conation". J. Hist. Behav. Sci., 16 1980. 107-117.

HOSCHILD, A. R. The Commercialization of Intimate Life: Notes from Work and Home. Berkeley and Los Angeles: University of California Press, 2003.

HUSSERL, E. La Crise des Sciences Européennes et la Phénoménologie Transcendentale. Paris: TEL-Gallimard, 1989.

KARMILOFF-SMITH, A. Beyond Modularity: a developmental perspective on cognitive science. Cambridge: MIT Press, 1995.

KIHLSTROM, J. F. \&. B. J. S.; KLEIN, S. B. "Self and identity as memory" In: LEARY, M. R.; TANGNEY, J. (Edits.): Handbook of Self and Identity. New York: Guilford Press, 2002. p. 68-90.

LACAN, J. O Seminário, livro 5: As formações do inconsciente. Rio de Janeiro: Zahar, 1999.

LEDOUX, J. The Emotional Brain: the mysterious underpinnings of emotional life. New York: Touchstone Books, 1996.

LEVY, R. I. Tahitians. Chicago: University of Chicago Press., 1973

LIEBERMAN, M. et al. "Do amnesics exhibit cognitive dissonance reduction? The role of explicit memory and attention in attitude change". Psychol. Sci. 12, p. 135-140, 2001.

MACRAE, C. et al. "Medial prefrontal activity predicts memory for self". Cereb. Cortex 14, p. 647-54, 2004.

MATURANA, H. A Ontologia da Realidade. Belo Horizonte: Editora da UFMG, 1977

MCLEAN, P. D. The Triune Brain in Evolution Role in

Paleocerebral Functions. New York: Plenum Publishiing Corporation, 1989.

MEAD, G. Espíritu, Persona y Sociedad. México: Paidós, 1993.

MOLON, S. I. Subjetividade e Constituição do Sujeito em Vygotsky. Petrópolis: Vozes, 2003.
NIETSZCHE, F. Obras incompletas (col. Os Pensadores). São Paulo: Abril Cultural, 1979.

OLIVEIRA, M. K.; REGO, T. C. "Vygotsky e as complexas relações entre cognição e afeto" In: ARANTES, V. A (org.): Afetividade na Escola. São Paulo: Summus, 2003.

PANKSEPP, J. Affective Neuroscience: The Foundations of Human and Animal Emotions. Cambridge: Oxford University Press , 1998.

PIAGET, J. O Juízo Moral na Criança. São Paulo: Summus, 1994. POSNER, M. I.; DIGIROLAMO, G. J. "Cognitive neuroscience: origins and promise". Psychological Bulletin, Vol. 126, No. 6 University of Illinois at Urbana-Champaign 2000. 873-889.

RENSINK, R. A. "Visual search for change: A probe into the nature of attentional processing". Visual Cognition, 7, p. 345-376, 2000

RICOEUR, P. A Metáfora Viva. São Paulo; : Loyola, 2000.

SAGAN, C. Os Dragões do Éden: especulações sobre a evolução da inteligência humana. Rio de Janeiro: Francisco Alves Editora, 1987.

TEIXEIRA, J.-M.. L. "Epigénese e desenvolvimento (1)". Saúde Mental, VOLUME IV julho/agosto 2002. editorial

TOTARO, P. Cultura do Cálculo e Desagragação Social. São Leopoldo: UNISINOS, 2010. 229 pgs. p.

WENTURA, D.; ROTHERMUND, K.; BAK, P. "Automatic vigilance: The attention-grabbing power of approach- and avoidance-related social information". Journal of Personality and Social Psychology, 78, p. 1024-1037., 2000.

WUNDT, W. M. Principles of Physiological Psychology. Nova York: Macmillan. (Trabalho original publicado em 1874), 1904. 